\title{
Performing LaW, Performing The City ${ }^{*}$
}

\section{INTRODUCTION. PERFORMING}

My recent ethical challenge has been to bring together my academic and my artistic practices. I am a legal academic, as well as a practicing artist. And while law has often been part of what I do as an artist, bringing my art practice into law has been harder. Perhaps because I know from within how conservative even progressive legal thinking can often be (with many exceptions). Perhaps a different fear stopped me - a fear of exposing other, non-academic sides of myself to an academic audience there to listen critically, ask questions and effectively judge. Or perhaps even a disciplinary phobia of too much mixing with risks of superficiality and obscurity. These fears however have now taken backstage in view of what I called an 'ethical responsibility'. I no longer consider interdisciplinary study, lecturing, researching and practicing as a luxury, an add-on or even an option. On the contrary, I have placed interdisciplinarity in the core of what I consider to be my ethical responsibility as a legal academic. Interdisciplinarity allows law to escape its frequently inhabited ivory tower. It helps law become more of a quotidian occurrence with its subsequently generalised transformative potential for people who would ordinarily consider the law a threat. It sets a political agenda for legal practice that caters to the ones who have been traditionally marginalised by the law. It gives to the legal academy an opportunity to experiment with the content, method and limits of the law.

This is the reason for which, when kindly invited by the organiser to talk at the McGill online Law and the City conference, I decided, rather than simply to talk about my work on law

\footnotetext{
*Andreas Philippopoulos-Mihalopoulos; Artist / Fiction Author / Professor of Law and Theory, Director of the Westminster Law \& Theory Lab, University of Westminster. Contact: $<$ www.andreaspm.com>.
} 
and the city, actually to perform it. This did not make my life easier. Quite the opposite. I would have welcomed the opportunity calmly to revisit my work on law and the city as it was back in $2007^{1}$ with the first book dedicated precisely to this juncture. I decided, however, that my responsibility lied elsewhere: not just to inform but to challenge in ways that legal conference goers do not often encounter. The online aspect of the performance made things in some ways easier and in others more complicated. But it has reached that point where I could no longer envisage this 'performance lecture' other than online.

In what follows, and due to the limitations of the current textual format, I trace the theory of law and the city in three sections, ${ }^{2}$ each of which is prefaced by a short description of the performance actions. Readers interested in it, however, can access it online. ${ }^{3}$

Overall, thinking of law and the city together is not a matter of simple disciplinary confluence but of ethical necessary responsibility. In other words, this is a call to position ourselves, aware of our choices and also our lack of choices. In order to do this, I offer three gifts to the reader. But every gift is also potentially a poison, Medea tells us. We need to be careful with each one of them because they might hurt us and others. These gifts are weapons, means of thinking, moving, staying put, resisting or accepting. They have no inherent direction or a priori moral value. They differ, depending on where they find themselves. They are crying for the taking up of responsibility.

\footnotetext{
${ }^{1}$ Andreas Philippopoulos-Mihalopoulos, Absent Environments: Theorising Environmental Law and the City (Routledge 2007) and Andreas Philippopoulos-Mihalopoulos (ed.), Law and the City (Routledge 2007).

${ }^{2}$ For further analysis, see Andreas Philippopoulos-Mihalopoulos, Spatial Justice: Body Lawscape Atmosphere (Routledge 2015) 3 See $<$ https://andreaspm.com/show/the-space-that-you-are/> accessed 12 October 2021.
} 


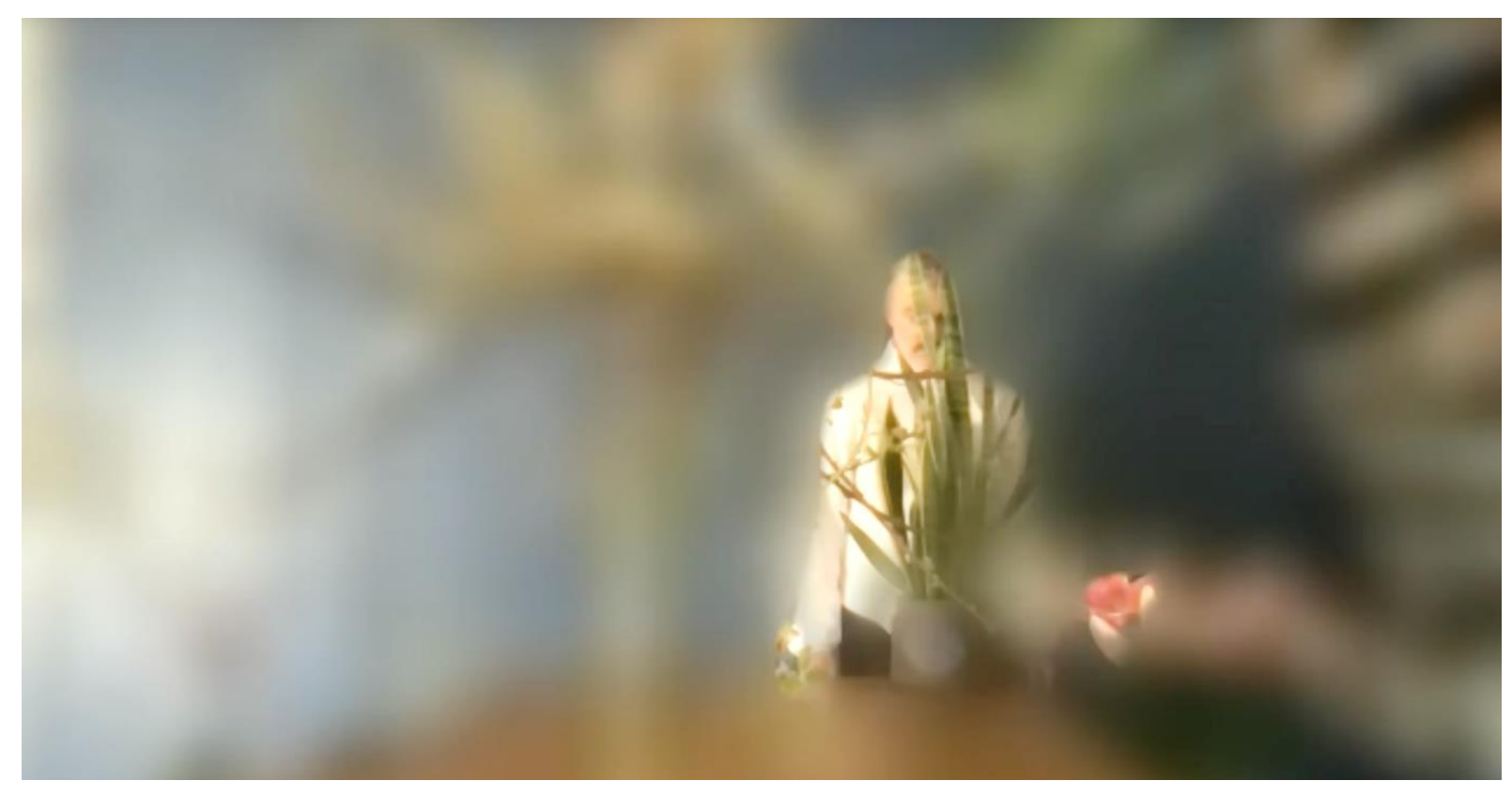

\section{PART 1. LAWSCAPE}

The screen space is blurred. The performer slowly enters the screen but he remains blurred, one with his environment. Plants or flowers occasionally grasp the screen's focus and the blur recedes. But only in relation to these. The body of the performer, dressed in white fencing outfit, slowly comes into focus. There is a song, repetitive and hypnotic, one sentence, something that sounds lifted from Nietzsche, a song that Zarathustra might have sung, in repeat, again and again: "There is no outside, yet we forget it. How lovely it is that we forget."

The first gift is like a toy that allows you to build worlds with it but might also bring about oppression, fear, confusion. The first gift is the lawscape. I define the lawscape as the tautology between law and space - and urban space in particular. The lawscape is the epistemological and ontological tautology of law and the city. 4 For what is law without city or city without law?

4 See also Philippopoulos-Mihalopoulos (n 2). 
A city without law can only be this fetish of a holy city of justice, perpetually floating in a postconflict space where everything is light and forgiveness. Likewise, a law without a city is a law without materiality, that other fetish (this time of legal thinking) that considers law to be an abstract, universal, immutable, what? Thing? Breath? Divine will? Act of violence? Both law without city and city without law are fantastic beasts that operate at best as horizon and at worst as cheap rhetoric.

Law is always spatially grounded, epidermally embodied, materially present. Law as an abstract universal, free from the constraints of matter and bodies and space is one of the illusions that law itself (and some strands of legal theory) insist on maintaining. Law as control is by necessity material (meaning spatial and corporeal), for it is only through its very own emplaced body that the law can exert its force. Law comes nowhere but from within the controlled, their bodies of appearance and the corridors on which they move, as post-colonial theory has taught us. ${ }^{5}$ This is more than just biopolitical control, since it addresses the material nature of the law itself: only from within matter can law control. Thus, to posit a law without a city is tantamount to positing, say, a universal human right that applies to everyone without the need for contextualisation. The latter is not 'just' the context. On the contrary, it is the supreme need to close in and eavesdrop on the particular body's specific circumstances. Even in the theoretical, indeed horizontal, possibility of a just city, the law's withdrawal would be a material one, its movement traced on the skin of the city, its back turned to the urban deification. In its turn, a just city has captured time itself, engraved it right here in its Edenic intramuros. There is no other way: a just city is a theological concept and cannot accommodate anything that falls sort of divinity. ${ }^{6}$ A just city does not belong to the lawscape except as a

\footnotetext{
5 Homi Bhabha, The Location of Culture (Routledge Classics 2005).

6 Cf. Susan Fainstein, The Just City (Cornell University Press 2010).
} 
horizon. And the risk of course is that the horizon can always be co-opted on behalf of cheap demagogy.

Law in the lawscape is not just the standard, written law. It is important to understand that the way I use law is not the traditional meaning of law as textual, written, enforceable etc. I am taking a radical distance from positivism, and I define the law as the rules that determine the way the various bodies, human and non-human, bodies and objects, move about - what Spinoza ${ }^{7}$ has called "rules for living". Human, nonhuman, inhuman bodies come together in creating and being created by the law. For this reason, I would talk about the law as an expansive institutional affect that permeates the formal and the informal, the abstract and the material. What is remarkable, however, is that the latter diffused form of normativity exhibits the paradox of appearing both as a corporeally embedded preference for individual selfpreservation, and a feature compliant with the current surveillance and control culture. This sense of normativity takes few risks and delegates conflict resolution to what it considers to be higher levels of judgment-making - indeed, to go back to Spinoza, a sort of guardian authority that pursues efficiently the individual interests of its subjects. The phenomenon of the "nanny state" is both an anathema and a desire, a direct result of which is the perceived political apathy. It is not all bleak though. This is a comfortable sense of normativity that covers specific needs, such as issues of belonging, constructions of home and community, as well as emplacement. It is, properly speaking, a product of its own spatiotemporal conditions, and as such it manages either to preserve itself as visibly unethical, oppressive, dictatorial, fascist indeed illegal regime (which, however, engenders its own legality); or to make itself invisible and neutral, to recede from the surface and conceal its force in the folds of its own legality. The latter, a phenomenon of most western societies, works both ways: legal subjects recede from

\footnotetext{
7 Baruch Spinoza, Theological-Political Treatise (Cambridge University Press 2007).
} 
actively questioning the law (complacency or reassurance), and the law recedes from claiming a role in the construction of the everyday. This does not mean that the law is not there - simply that it is not perceived as being constantly there. This is a strategic move that aims at diffusing and dissimulating the force of law, offering instead a smooth, anomic atmosphere. Even so, things can on occasion overflow, exceed themselves and embark upon a flight of radical selfredefinition. In such cases, the already 'contagious' (in the sense of epidemic imitating, see Tarde, 1903) nature of the normative doubles up and becomes rapid, horizontal and fiery, engendering such eruptions as demonstrations, revolts, revolutions, coups. In all these cases, the law does not leave the stage. It is merely supplemented by a different normative direction and sometimes a higher velocity.

The performer, now in full focus, starts drawing lines with black ink on his face. The face becomes striated, separated in boxes by contingent, random boundaries.

City on the other hand is the thick spatiality of bodies (humans, nonhumans, linguistic, spatial, disciplinary), buildings, objects, animals, vegetables, minerals, money, communication, silence, open spaces, air, water, and so on. This spatiality is a fractal manifestation of what I have elsewhere called 'open ecology', ${ }^{8}$ namely the assemblage of the natural, the human, the artificial, the scientific, the political, the economic and so on, on a plane of contingency and fluid boundaries, or as Andrea Brighenti puts it, "a series of territories, which can be thought of as superimposed...or mutually exclusive...or even criss-crossed and overlapping." ${ }^{9}$ The open

\footnotetext{
${ }^{8}$ Andreas Philippopoulos-Mihalopoulos, “....the sound of a breaking string”: Critical Environmental Law and Ontological Vulnerability' (2011) 1:2 Journal of Environmental Law and Human Rights 5 (n 1b). 9 Andrea Brighenti, 'On Territory as Relationship and Law as Territory' (2006) 21:2 Canadian Journal of Law and Society/ Revue Canadienne Droit et Société 65.
} 
ecology of the city is simultaneously open and closed. Hinterlands, globe, outer space, hybrid technohumans, technologically manipulated meteorological phenomena 'and so on' (see Anna Grear's 2011 collapse of the anthropomorphic effigy $)^{10}$ are all grounded on the urban materiality of here, itself open to any definition of materiality may come from over there. Thus, while infinite, open ecology is entirely immanent. Any transcending movement is inscribed within, in the recesses of the unknowable here. There is nothing that is not, actually or virtually, included in open ecology. And nothing that is not, actually or virtually, connected to everything else in some form of connection that enables everything to become everything else. This is a processual rather than value-based ecology and, to quote Deleuze and Guattari, "we make no distinction between man and nature: the human essence of nature and the natural essence of man become one within nature in the form of production of industry". ${ }^{11}$ Instead of a distinction, a fractal fluctuation between human/artificial and natural. Instead of one city, an infinite multiplicity that repeats itself as difference.

There is a further movement within the lawscape. The surface of the lawscape enables the reciprocal dissimulation of law and the city. On a basic, phenomenological level, every single one of us regularly uses the lawscape in various ways: even a walk to the shop to pick up milk takes place in the lawscape (you enter a legal transaction where you are exchanging money for a product); but the lawscape is not fully fixed. There is a certain amount of flexibility, which allows us to play with it in various ways, to invisibilise the law. Say that you realise you have forgotten to take money with you. You are, however, friendly with the shop-keeper and agree that you will pass by later on the same day to pay what you owe. The traditional lawscape would

\footnotetext{
${ }^{10}$ See Anna Grear's collapse of the anthropomorphic effigy in Anna Grear, 'The vulnerable living order: human rights and the environment in a critical and philosophical perspective' (2011) 2:1 Journal of Human Rights and the Environment 23.

${ }^{11}$ Gilles Deleuze and Félix Guatarri, What is Philosophy? (Columbia University Press 1988) 4.
} 
dictate that you have to pay, otherwise you cannot buy. But the way you have negotiated the lawscape means that you can have some milk for your morning coffee, and simply pay for it later. The ontological aspect of this is that law and the city become mutually exclusive in their emergence, thus dissimulating and diffusing the otherwise oppressive nature of the lawscape. In that way they can both carry on with their self-perpetuating myths, such as the selfdescription of a city as an accueil of difference and the breeding ground of communitarian nostalgia, and of the law as a universal good that has the potential of universalising values such as right and wrong. Some elements remain, however, despite the very grounded and strategically engineered attempts at dissimulation. These are elements of the lawscape itself, which however change in degree according to the conditions of the specific lawscape. First, the inescapable lawscape. Wherever one is in the city (and arguably beyond it, in its global hinterlands), one swims with and against the various normative flows that constitute the materiality of its lawscape. Second, the posthuman lawscape. Defining the city as a slice of open ecology means that the lawscape lies beyond such distinctions as human/natural/artificial. ${ }^{12}$ Third, the fractal lawscape. While each lawscape is different, they all fractally repeat the reciprocally invisibilising embrace between open normativity and open ecology. There is no global lawscape that operates as a semantic and material common surface for the totality of cities, yet there is a plane of immanence, not unlike the earth or nature as Deleuze and Guattari put it. ${ }^{13}$ This plane consists of lawscapes but also trammels the lawscapes, constantly pushing them along new lines of flight, namely internal planar movements that begin and end within the plane of immanence yet push the edges of the plane always further. An example of such a line of flight would be the creative or competitive edge of any city that wants to attract the globe

\footnotetext{
${ }^{12}$ Carrie Wolfe, What is Posthumanism?(University of Minnesota Press 2009).

13 Deleuze and Guattari (n 11).
} 
and that, by placing itself alongside other cities, manages to develop creatively its own potential.

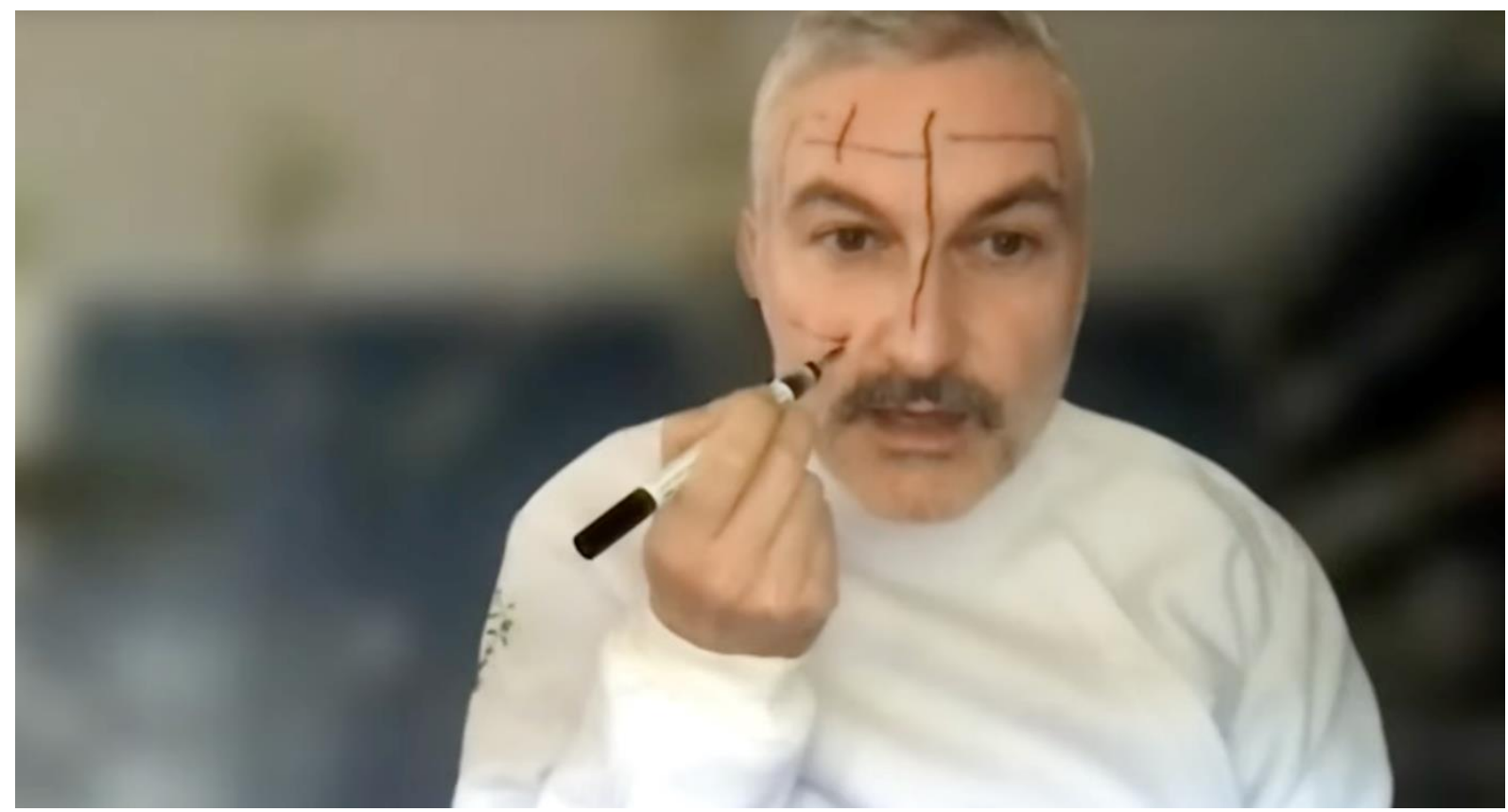

What is proposed here, largely following Deleuze and Guattari ${ }^{14}$ on their 'alloplastic stratum', namely the level of creative construction of signs not limited to humans, is a decentring of whatever residue of centrality might remain in the configuration of the connection between the human and the environmental. ${ }^{15}$ This entails a radical opening of both understandings of the city and the law towards an unmediated wilderness. At the same time, however not all bodies are equal. Human, animal, vegetable, inorganic, semantic, discursive bodies are characterised by different viscosities, different concentration of power in relation to other bodies and consequently different affective abilities. Thus, in the lawscape human affective abilities are

\footnotetext{
14 Deleuze and Guattari (n 11) 314-317.

15 Which sets the lawscape apart in relation to other fusions of the legal and the spatial, such as the nomotop - see Peter Sloterdijk, 'The Nomotop: On the Emergence of Law in the Island of Humanity' (2006) 18:1 Law and Literature 1-14 - or the nomosphere - see David Delaney, The Spatial, The Legal and the Pragmatics of World-Making (Routledge 2010).
} 
regularly stronger than animal affective abilities, but both are subject to the affective abilities of meteorological, geographical, or even complex social phenomena that construct specific corridors of urban movement.

A disembodied voice, yet still the voice of the performer, is heard above the actions. It gives instructions to the conference participants. Their cameras are on, their screen space is available for their bodies to move into it and use it. The voice insists that people follow the instructions. The instructions are multiple, in sequence. They might sound meaningless.

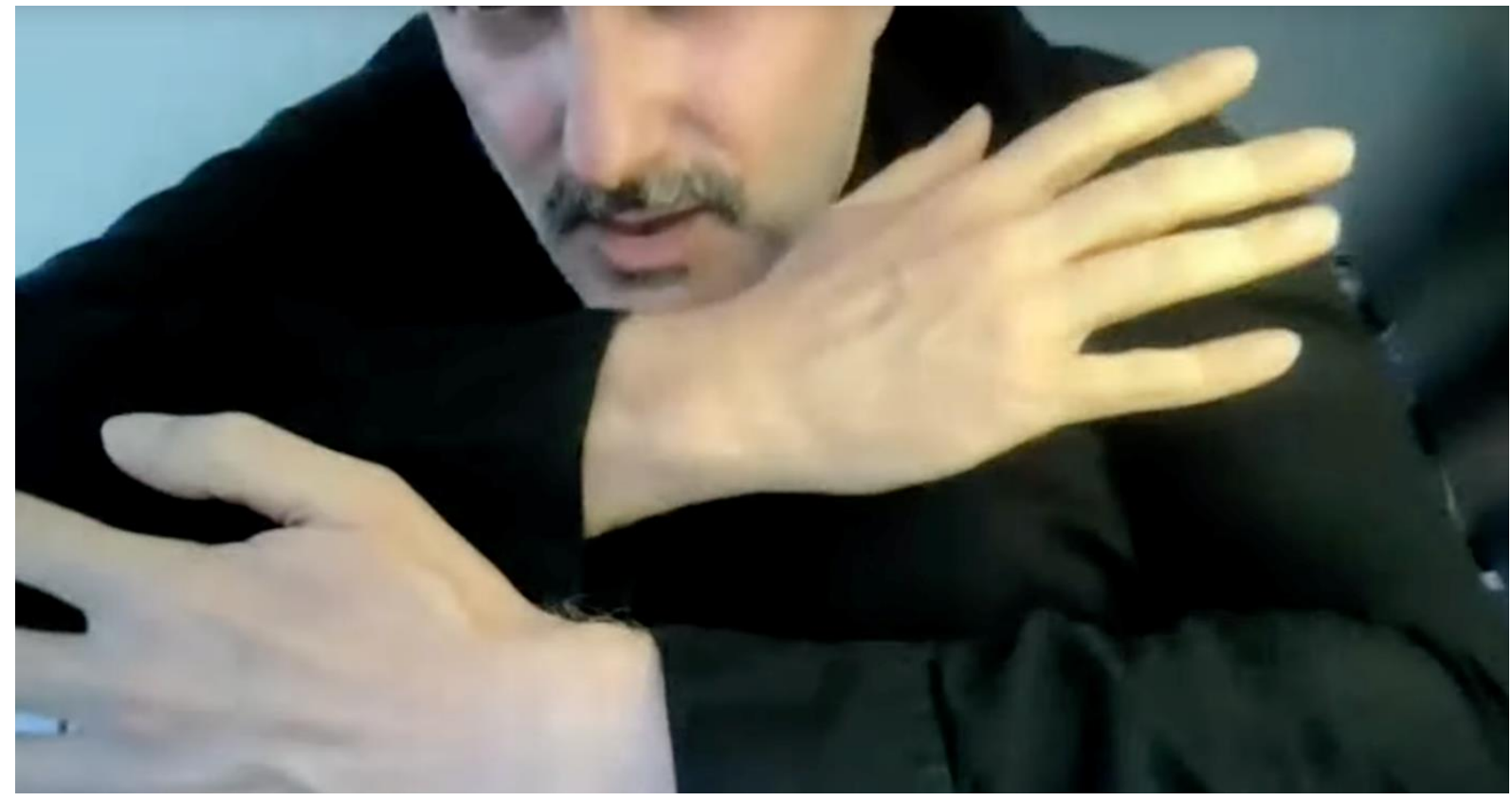

\section{PART 2. ATMOSPHERE}

The performer takes off the white fencing suit and remains with a black dress shirt. A video of an empty air balloon, its edges caught between buildings, bellows and moves in an invisible air. 
The second gift is a little harder to handle. At first, it feels quite lovely and comfortable, indeed natural or at least inevitable. It feels like a soft blanket that one places around one's shoulders on a chilly evening. But it is imperative that we do not dwell on this feeling for too long, for otherwise we become enslaved in it. This gift needs to be treated in a non-judgemental, understanding way (we all need a soft blanket at points) but also with suspicion. The second gift is the atmosphere. An atmosphere is what brings together the various bodies, and keeps them together for as long as it can. It relies on affect, and specifically affective excess, namely the sensorial, symbolic and emotional 'glue' that circulates in and between bodies. Atmosphere uses affect and brings bodies together, but not necessarily in a benign, community-like way. Atmosphere attracts. An atmosphere has it all: oxygen, water, horizon, future, comfort, productivity, belonging, imperceptibility. Above all, it is all there is: ${ }^{16}$ life cannot survive outside it. Atmosphere excludes and burns anything that approaches it. Any venturing outside is premised on the condition that a small chunk of the atmosphere will be taken along, a memento vitae in a glass bowl. Atmosphere spans the geological, the psychological, the scientific, the political, the legal, and appears differently in each one of these. Indeed an atmosphere might appear different even to different individuals. Yet, and although connected to bodies and their affective connections, and occasionally apprehended by consciousness, atmosphere is not a phenomenological entity because it does not depend on apprehension. ${ }^{17}$ If anything, atmosphere is preconscious and can only be apprehended post-facto. Furthermore,

\footnotetext{
16 "Atmospheres are made available as total settings of attractions, signs and contact opportunities" Peter Sloterdijk, Sphären III: Schäume. Plurale Sphärologie (Suhrkamp 2004) 180. See also Peter Sloterdijk, 'Atmospheric Politics' in Bruno Latour and Peter Weibel (eds), Making Things Public (MIT Press 2005).

${ }^{17}$ This is explicitly against Gerhard Böhme's understanding of atmosphere as "the common reality of the perceiver and the perceived" - Gerhard Böhme, Atmosphäre (Suhrkamp, 1995) 34. For my objections to this and further atmospheric analysis, see Philippopoulos-Mihalopoulos (n 2).
} 
atmosphere does not engage with the distinction between subject/object, but indeed with the indistinguishability between the two. Finally, atmosphere is properly speaking rhizomatic: it does not begin from one or the other side (subject/object, space/time, consciousness/body), nor does it have a prescribed direction of movement, but rather floats on the common surface of parallel unfolding, which is neither an in-between, nor a synthesis. Thus, I define atmosphere as the excess of affect that keeps bodies together; and what emerges when bodies are held together by, though and against each other.

Atmospheres rely on affects, consist of affects and help maintain and direct affects. Atmospheres are (always) affective. ${ }^{18}$ At the same time, they emerge in the space of affective excess in two ways. First, in terms of time. Massumi defines affects as "virtual synesthetic perspectives anchored in (functionally limited by) the actually existing, particular things that embody them." ${ }^{19}$ An affect can never be fully captured and assimilated - it is both plural ('synesthetic') and future-tending ('virtual'). Massumi uses the virtual here in the Deleuzian sense of horizon of potentiality, of not yet but potentially actualised actuality. The affect's inability to be fully captured, the "escape of affect" 20 is at the same time its ability to capture the virtual. Although firmly rooted in the here of the body, the affect protends to its virtual becoming. Second, affective excess is material: "affects go beyond the strength of those who undergo them... Affects are beings whose validity lies in themselves and exceeds any lived". ${ }^{21}$ An atmosphere relies on the affect exceeding the body of its appearance, since atmospheres establish themselves through imitation or contagion. In her psychoanalytical work on affective

\footnotetext{
18 Ben Anderson, 'Affective Atmospheres' (2009) 2:1 Emotion, Space and Society 77.

19 Brian Massumi, Parables for the Virtual: Movement, Affect, Sensation (Duke University Press 2002) 35 .

20 Ibid.

${ }^{21}$ Gilles Deleuze and Félix Guattari, What is Philosophy?(Columbia University Press 1994) 164.
} 
transmission, Teresa Brennan ${ }^{22}$ has shown through clinical observation how affects are transmitted from bodies and spaces to other bodies and spaces. This is Sloterdijk's ${ }^{23}$ point when he refers to Gabriel Tarde's concept of imitation. ${ }^{24}$ Affective imitation spreads like grass amongst the bodies and spaces of these bodies, co-originating in the various milieus and giving rise to an atmosphere.

The disembodied voice is heard again. This time the performer probes us all to obey to the voice, to do what the voice is asking. He does it himself, filling the screen with his body, and contorting his limbs so that to do exactly what the voice is asking, all the while asking the participants to really participate, to create a community, indeed an atmosphere together.

Atmosphere is an engineered bubble of self-containment and consequent exclusion of anything that does not fit the very atmosphere. An atmosphere is something we need, and indeed constantly construct (in our homes, our restaurants, our planet); yet, at the same time, it is something regularly co-opted and engineered towards excessive and needless consumerism, sense of passivity and political apathy, fear and hate of the Other outside (the refugee, the indigenous, the Other politically, religiously, culturally etc). Cities are the perfect example of atmospherics in practice: inclusion and exclusion, communities and undesired, belonging and marginalised, and indeed consumerism as the main way to interact in the city. An atmosphere is produced by a partitioning of material and immaterial elements, such as space, air and

${ }_{22}$ Teresa Brennan, The Transmission of Affect (Cornell University Press, 2004) 170.

23 Sloterdijk (n 15).

24 Gabriel Tarde, The Laws of Imitation (H. Holt 1903). 
affects. Once in there, the participating bodies do not even have the desire to escape. This is the most dangerous aspect of an atmosphere: the participating bodies desire the very continuation of the atmosphere. They have taken the song too literally, and have completely forgotten. Because, although there is no outside, there is a need to keep on dreaming of it.

To sum up, atmosphere is a spatiotemporal and corporeal emergence whose effect on society can be engineered towards specific goals. However, since its emergence and maintenance relies on the excess of affective contagion, there is no way in which one can be certain that the desired effect will be achieved. Atmosphere is, after all, air, gas, vapour, extending in uncontrolled ways and dissolving without notice. It is within these parameters that one can talk about an atmosphere conducive to knowledge or creativity. It is not merely a matter of cosying-up the office space. The act of atmospheric engineering is itself creative and demanding. It must take into account that it operates partly as a net of spatiotemporal affective movements, and partly as a space of exclusion of anything that might destabilise the interior stability of an atmosphere. This means that often atmospheres need to dissimulate themselves as the only space in which the specific event (whatever the main event of an atmosphere might be) can take place. This requires a strategy of dissimulation of the continuity that any atmosphere has with its outside (it is air after all), creating thus what Sloterdijk has called bubbles, namely immune totalities that exclude the outside while inside appearing safe and, in our case, creativity-conducive. Although an atmosphere is not an ethical space, it is nevertheless a space where ethical questions arise. Since atmosphere is all there is, it follows that inside an atmosphere there is hardly any space for questioning or resisting. This means that decisions that lead to the emergence and maintenance of an atmosphere must be placed within a milieu that enables horizontal cross-checking and cross-control. 


\section{PART 3. SPATIAL JUSTICE}

A large jigsaw puzzle, its pieces tightly wound together, is being slowly undone. Two hands treat the puzzle as a stretched piece of textile or a paper that, no matter what, it won't tear. The hands underneath the surface of the puzzle shake it and move it and the puzzle surface starts to crack till it becomes all individual pieces.

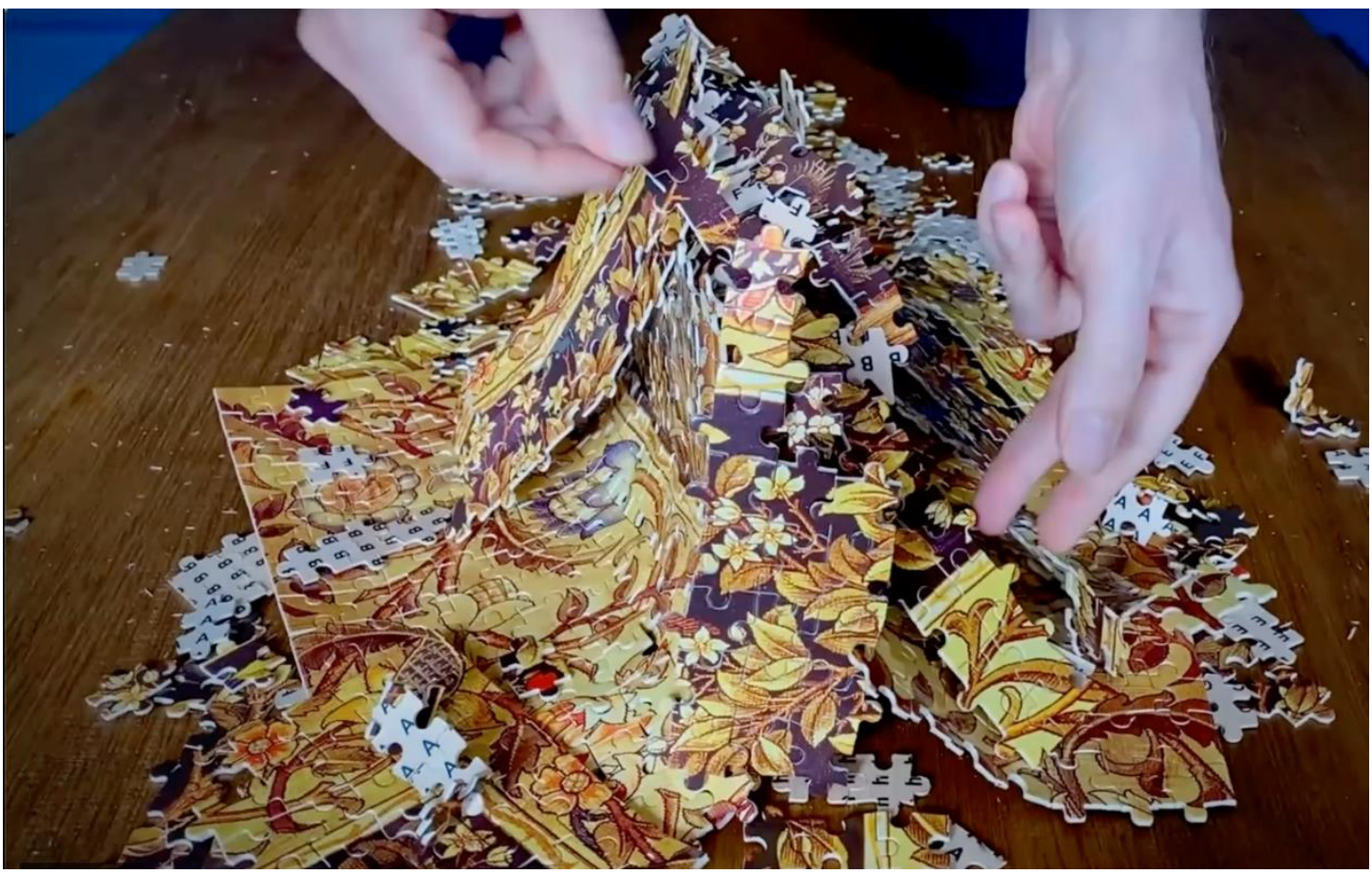

With this, we have reached the third gift. You will need to juggle that gift, now on one hand, now on the other. It cannot remain in only one for too long. It requires movement, constant questioning, opposition to any complacency that might come from atmospherics. The third gift is spatial justice. I understand spatial justice in a radical, spatialised and corporeal manner. It is the question that arises when a body wants to be in precisely the same space at precisely the same time as another body. Spatial justice is not a solution, not even a state of being. It can be achieved but needs to be constantly questioned. It is not the answer to the above question, but 
simply the awareness of the question. Spatial justice demands assuming responsibility for our spatial positions with regards to other bodies. It is not about who came here first. It is about opening up to the question of why we should think that we have more or better right to this space, than others. Spatial justice is in the core of all contemporary issues that involve bodies moving in space - so, everything is related to the question of spatial justice. But it can be observed more eloquently in global geopolitical issues of territorial claims and access to resources; while losing nothing of its relevance when observed in quotidian situations of the way in which we behave towards other bodies.

I am interested in thinking of spatial justice, not so much as rupture (although it can also be that) but as a process of repetition that produces difference. In that sense, spatial justice is the interstice par excellence: it continues the interstitial tautology of law and the city through the repeating movement of its very own body of emergence. As I explain below, therefore, spatial justice is not the ground or indeed the final destination (in the sense of the just city) of various juridical claims. Rather, spatial justice is a movement, embodied, emplaced and thoroughly material.

Spatial justice emerges from within an atmosphere as a gesture of withdrawal from the atmosphere. Spatial justice - the ethical responsibility to question our emplacement - can only take place when one withdraws from the numbing atmospherics of unquestionable positions. The very act of withdrawal, not a passive act of surrendering but on the contrary a revolutionary act that ruptures the atmosphere, is the moment of spatial justice, namely the point where the potential of spatial justice becomes palpable. Of course, one must not be fooled. There is no outside, whether of the atmosphere or the lawscape, or indeed the vast ontological continuum. By withdrawing from the atmosphere, one ends up nowhere else but the lawscape. But this movement of withdrawal has allowed for the rupture of the atmosphere and opens up the space 
of negotiation that the lawscape is. And the hope of spatial justice is this: that a new, differently-oriented lawscape will be emerging, where the conflict will be negotiated differently, perhaps closer to justice, perhaps in greater recognition of the rights of the other. This is the hope of spatial justice.

While the term spatial justice has been around for a while, markedly since David Harvey 25 introduced the concept in the 1970 s, the way it has been employed since is either flaccidly uneventful or bombastically originary. The main issue with these approaches is that they carry on with preoccupations of being rather than becoming, namely origin and destination and boundaries (and consequently control and claiming) rather than emergences (and therefore, processes of speed and stasis) that often lie beyond mere human control. What is more, the law is ignored and replaced by politics of rights to the territory, access to resources and democratic processes of participation - all relevant, yet none managing to capture the normative force behind the lawscape, namely the force with which the body of the law affects other urban bodies as well as the urban body as a whole in becoming the lawscape. At worse, spatial justice becomes an anaemic metaphor that talks about social inclusion and equal distribution, managing thus to ignore the violent, exclusionary and directionless nature of space. Indeed, spatial justice becomes aspatial.

This is where my concept of spatial justice comes in. It all begins with a betrayingly simple formation: one body and other bodies. And then, right in the middle of this, the desire for movement: I want to be where you are, exactly there, exactly then. The motives (greed, attraction, possessiveness, territorialism, reterritorialisation) can be put aside for the time being, for what is important is the desire for justice, the act of moving, of passing, of being

25 David Harvey, Social Justice and the City (Blackwell 1973). 
deterritorialised by the spatial position of the other - that is by allowing the position of the other to make her territory out of my position.

The performer brings out a small round mirror and points it towards the camera. The mirror captures the image of the screen and repeats it infinitely, a mise en abyme, one reflection enclosed in the one before that, a multiplicity of performers and a multiplicity of participants, bodies vying for the same space at the same time.

The need for justice arises as soon as the lawscape emerges - namely, as soon as law and space become each other, partitioning space and territorialising law through paths of spatial normativity. There is of course no one originary point at which law and city merge but there are specific points at which the conflict between their various manifestations becomes apparent. Paths cross each other, bodies clash, geopolitical presences are not tolerated, homeless bodies are shoved under the bridge, veiled bodies are shut indoors, religious adversaries are housed next to each other, the industry moves into the forest, the ship moves into the fish stock: in all these movements, there is conflict. Spatial justice is the movement out of this conflict while delving deeper into it.

With this, we move into the other important role of spatial justice, that of a political position: spatial justice is the emergence of resistance against the omnipresence of the law. If the lawscape is all there is, it means that the law is material through and through, and that there is no space free from law. Even a smooth space has its own, nomadic law, the nomos that moves on the surface of the earth. Law and the city flow together in a way that it is impossible to tell them apart, capturing all there is. So where is the space of resistance? Where can one find a sliver of escape from the rapturous nuptials of law and space? This is where withdrawal 
comes in: a removal from the space of the law, a movement of bodies away from the embrace. Withdrawal is not an isolated movement, at least in the sense of a directed displacement. Rather, it is a shift that mobilises the space, the bodies on this space and the legality that trammels their connection. Withdrawal is a tectonic shift that takes with it the surfaces on which the law appears. A body withdrawing is lawscape withdrawing. But this is precisely the movement of justice. In order to employ the law justly, one (a judge, a lawmaker, a collectivity) needs to destroy the law, to let the whole legal edifice collapse, to withdraw from it - and only then will the law regroup and reach a judgment that might or might not be just. One moves one's body away from the law, withdraws one's corporeal attachment to it and sees the law in full materiality. The withdrawal can only take place from inside and within the lawscape, hammering right at its foundations and up to its turrets. In withdrawing from the lawscape one does not move outside. There is no better place outside. There is no better law, better city, better justice. It is all part of an infinite plane of immanence on which withdrawal moves. If justice is to be materialised, withdrawal must be kept immanent. This amounts to more than a manipulation of the law, a new interpretation or a legal stuttering. Nor does it mean that one has to work with the system. Rather, it is a denial of the law, a questioning of its relevance, its validity and even its lawfulness. Withdrawal rides the waving banner of the unutterable legal paradox: is the law lawful? Take the example of a revolt against the government. Revolts work from outside the lawscape in that they assume the difference in materiality between 'us' and 'them'. The police is not us, the fellow citizen is not them. It is a necessary suspension, an inclusion of negation. Yet whatever change takes place with a revolt, it will have to be within the lawscape. Materiality reunited. Which lawscape is that? A brand new lawscape? No doubt; but also a very old lawscape. A piece of the lawscape must be preserved in order for the lawscape to assemble itself every time after every withdrawal. The withdrawal has to be 
registered by the lawscape: speak the law's language, enter the law's dreams, touch the law's extremities. Revolting is withdrawing, but withdrawing is immanent. One cannot achieve justice by revolting alone.

Spatial justice is distanced from historicisation and thrown in at the space of here, namely the space that vibrates with history through its material appearance. Not an abstract history but a history of the here. Not a history that legitimises atrocities but a history that accepts the need for bodies to be here, exactly where other bodies might also want to be. Justice is a conflictual space, full of erupting laws and spreading normativities. For justice away from the law is not a lawless justice. It is certainly a risky, potentially dangerous space, emptied of pillared security and smooth lines. It is also a space of constant reconstruction, rapid concept formation, applied acrobatics of thought and action. A space of justice - and indeed spatial justice - is a space where the law is being erected at every moment as if for the first time. Like a group of nomads that must set up home every time they stop for the night, in the same way the law is re-erected through a repetition that might create difference. This is where we come full circle: withdrawal leads to repetition that leads to withdrawal. The two are not opposites but share one surface: that of stasis. Faithful to its etymology, stasis is both pause and revolt, withdrawal and return. Stasis is nomadic. For it is not the case that the nomad moves constantly. As Deleuze and Guattari ${ }^{26}$ put it, "it is false to define the nomad by movement." It may be the case that the nomad moves from point to point to a further point, but the points are there by necessity. The nomad always moves along paths or trajectories that simply happen to include points. In that sense, the nomadic movement is, as the authors write while referring to Heinrich von Kleist, "immobility and speed, catatonia and rush, a "stationary process," station

\footnotetext{
${ }^{26}$ Deleuze and Guattari (n 11) 420.
} 
as process." ${ }^{27}$ The nomadic movement is the "absolute movement", or the speed in which the body "in the manner of a vortex" swirls in palpitating stasis. In that sense, the body carries the smoothness within, as it were, and moves between various positions in striated space.

Spatial justice is not a synthesis and it is not a solution. It is a question that might lead to a different plane of articulation of the conflict. A fairer, more just articulation that might lead to fairer, more just negotiations where the parties will be on an equal or at least comparable footing. Spatial justice requires us to withdraw from the vocabulary that has served us well so far.

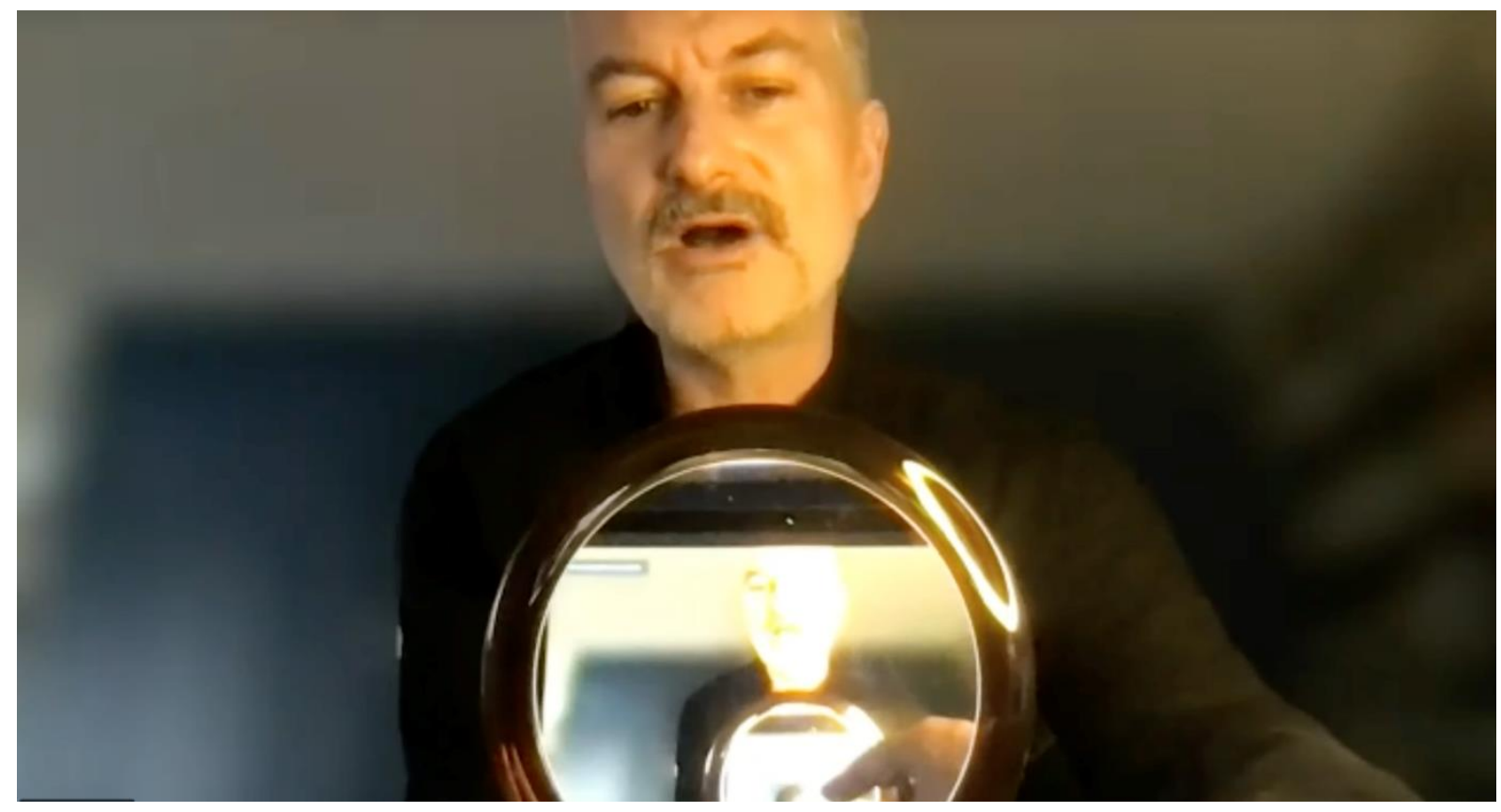

Withdrawal is a form of becoming other, but with a political, indeed strategic direction; it is most often collective rather than individual (just as every body is a collectivity); and the destination of the withdrawing body cannot be prescribed with certainty. It is a movement away from and not towards something; withdrawing is walking with one's back turned to the

27 Ibid. 
destination. What counts is the departure. In that respect, is as unpredictable and potentially harmful as any other concept offered here. In a way, withdrawal is the real gift of this text, truly empowering but also truly dangerous. One makes of it what one can.

The performer touches the edge of his screen and extends a hand to the screen next to him. He is inviting the one in the square next to his to extend their hand too and touch. 